\title{
Purchasing Car Insurance: What College Students Should Know ${ }^{1}$
}

\author{
Nicholas Horvath, Jorge Ruiz-Menjivar, and Sarah M. Ellis ${ }^{2}$
}

\section{Car Insurance in Florida and the United States}

Florida law requires drivers to have car insurance that provides financial protection in the event of a mishap. Insurance companies (the insurer) provide coverage that protects the client (the insuree) from financial loss through a contract (the policy) in exchange for premium payments. The company providing the insurance will cover financial obligations and represent the client up to the limits of the policy.

All Florida car owners and drivers must carry car insurance. Motorcycles and mopeds are covered under financial responsibility laws. Florida law requires car owners to carry a minimum insurance protection of $\$ 10,000$ property damage liability per accident and $\$ 10,000$ personal injury protection. In addition, Florida is one of only 13 states and territories that are considered no-fault for car insurance purposes. In a no-fault car insurance state, when you have an accident, your auto insurance company automatically covers certain damages (e.g., medical-related bills for the driver or passengers injured in a car accident), regardless of fault, up to a specified limit (the monetary or verbal threshold). Monetary threshold is the dollar limit damages must exceed before the injured party can sue. Verbal threshold states define specific categories of injuries or conditions that allow civil legal proceeding. Florida, Hawaii, Kansas, Kentucky, Massachusetts, Minnesota, North Dakota, and Utah have monetary threshold for coverages as no-fault, while Puerto Rico, Michigan, New Jersey, New York, and Pennsylvania have verbal thresholds for no-fault coverage.

\section{Insurance Coverage: Terminology and Minimum Requirements in Florida}

In Florida, Personal Injury Protection (PIP) and Property Damage Liability (PDL) are required coverages. All other coverages on the market are optional, but consumers often select them as well (Florida Department of Highway Safety and Motor Vehicles, 2017). If your vehicle is financed, the lender may require a full coverage policy. Additionally, a consumer might decide to purchase a policy that provides coverage above the state-mandated minimum to protect their assets and minimize their risk of being sued in the event of an auto accident.

When shopping for auto insurance, start with the required coverage. Ask yourself if you have the funds to replace or

1. This document is FCS3356, one of a series of the Department of Family, Youth and Community Sciences, UF/IFAS Extension. Original publication date January 2021. Visit the EDIS website at https://edis.ifas.ufl.edu for the currently supported version of this publication.

2. Nicholas Horvath, undergraduate student, Department of Family, Youth and Community Sciences; Jorge Ruiz-Menjivar, assistant professor, Department of Family, Youth and Community Sciences; and Sarah M. Ellis, Extension agent I, UF/IFAS Extension Citrus County, and graduate student, Department of Family, Youth and Community Sciences; UF/IFAS Extension, Gainesville, FL 32611.

The use of trade names in this publication is solely for the purpose of providing specific information. UF/IFAS does not guarantee or warranty the products named, and references to them in this publication do not signify our approval to the exclusion of other products of suitable composition.

The Institute of Food and Agricultural Sciences (IFAS) is an Equal Opportunity Institution authorized to provide research, educational information and other services

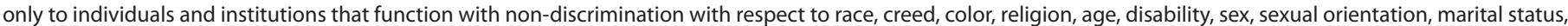

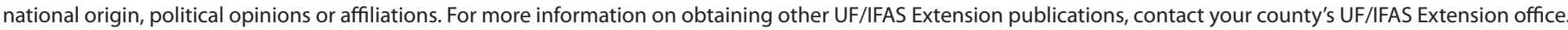
U.S. Department of Agriculture, UF/IFAS Extension Service, University of Florida, IFAS, Florida A \& M University Cooperative Extension Program, and Boards of County Commissioners Cooperating. Nick T. Place, dean for UF/IFAS Extension. 
repair your vehicle after a serious accident. If the answer is no, then you may want to add collision and comprehensive coverage. Do you have the funds to rent a car while your vehicle is being repaired? If not, you may want to consider rental reimbursement coverage.

College students who know what coverage terms mean and what the state law requires can navigate the variety of choices on the market to find the right coverage for their vehicles and financial situations. See the glossary of car insurance terms with Florida-required minimums below to learn more about insurance terms and coverage amounts.

\section{Glossary}

Bodily Injury Liability: Coverage that pays for expenses related to the injury or death of another driver or a pedestrian when in an accident that is your fault. The required Florida minimum is $\$ 10,000$ limit per person $/ \$ 20,000$ limit per accident. Typical coverage amounts are $\$ 100,000$ limit per person $/ \$ 300,000$ limit per accident.

Collision Coverage: Helps to pay expenses to repair or replace your vehicle if it is damaged in an accident. NOT REQUIRED in Florida, but often selected with a $\$ 500$ or higher deductible amount for newer, more expensive vehicles.

Comprehensive Coverage: Covers expenses to repair or replace your vehicle if it is damaged in a situation that is beyond your control, such as a storm or carjacking. NOT REQUIRED in Florida, but often chosen with a $\$ 250$ or higher deductible amount.

Medical Payments Coverage: Add-on coverage for you and/or your passengers and pedestrians if injury in an accident occurs. It covers medical or funeral expenses. Because PIP covers many of the same expenses, this is NOT REQUIRED in Florida and not typically added as optional coverage.

Property Damage Liability (PDL): Provides coverage for expenses related to the damage of another person's property, such as vehicles, homes, buildings and other structures, that you, a family member, or someone driving your car with permission caused while driving. The required Florida minimum is $\$ 10,000$ limit. Typical coverage amounts are $\$ 50,000$ limit.

Personal Injury Protection (PIP): Also known as "no-fault insurance," this covers medical costs of you and/or your passengers if you are hurt in an accident. The required
Florida minimum is $\$ 10,000$ limit Emergency medical condition $/ \$ 2,500$ Non-emergency medical condition. The typical coverage amount tends to be the state-required minimum.

Rental Reimbursement Coverage: This coverage helps pay for a rental car or other transportation if your vehicle needs repairs for a claim covered by insurance. NOT REQUIRED in Florida, but may be a good addition if you rely on your car. Policy limits include a daily and total claim maximum. The daily maximum limit is the total per day cost insurance will pay for the rental car. The total claim maximum may be a dollar amount or amount of time.

Roadside Assistance Coverage: Provides assistance including towing or transport if your vehicle breaks down. Coverages vary depending on the company. NOT REQUIRED in Florida. May be included with the purchase of a new car. Additionally, some cell phone companies and credit card companies offer this coverage.

Uninsured Motorist Coverage: Provides coverage for medical expenses if you're in an accident with a driver who is at fault and does not have insurance. NOT REQUIRED in Florida. However, this coverage is still good to have because Florida has the highest number of uninsured motorists at 26.7\% (Insurance Research Council, 2017). Typical coverage amounts are $\$ 10,000$ limit per person $/ \$ 20,000$ limit per accident.

Underinsured Motorist Coverage: Covers medical expenses if you are in an accident with a driver who is at fault and does not have enough insurance to cover the damages. NOT REQUIRED in Florida and may be grouped with uninsured motorist coverage.

\section{Discounts: College Students}

Many car insurance companies offer discounts to highperforming college students. To qualify for this discount, students must typically be 25 years old or younger and enrolled full-time at a college or university, maintain a 3.0 grade point average, and provide a copy of their grades or other documentation as requested.

\section{Issues Relevant to College Students}

In Florida, car insurance coverage options have not changed much as a result of the Affordable Care Act because there is an opt-out fine/tax option that young adults can select. They can pay the federal fine rather than 
purchase any health insurance, which would then apply if in an accident the PIP portion of the Florida mandate does not overlap. However, this opt-out option is not possible for most Florida students. As part of registration, most Florida colleges and universities require students show proof of health insurance provided by themselves or their parents, or included in their school charges. Still, there may be situations where health insurance requirements overlap-specifically, Uninsured and Underinsured Motorist coverages. College students should explore options to better align coverage and avoid paying for extra, unneeded coverage. The following case study explores options and coverages that might be best for a college student driver with a vehicle.

\section{Case Study: The Example of a College Student}

Consider a 20-year-old male college student with a GPA of 3.0, with no prior accidents or motor vehicle infractions and owning one of two possible vehicles.

Coverage options are Minimum Package, Standard Package, and Upgrade Package.

Table 1 lists coverages and limits.

Vehicle 1 is a 1996 SUV and vehicle 2 is a 2015 crossover (CUV) with values listed below.

Because most registered Florida university students have health insurance as a requirement of registration, Uninsured and Underinsured Motorist coverage is not required. One can avoid the cost of this coverage simply by signing the election of "no coverage" form that most companies use. Another way to reduce costs by over $50 \%$ of those listed below is by grouping the college student driver under their parents' coverage. Based on the online quotes received from a Large Insurance Company ${ }^{*}$, insuring vehicle 1 at the minimum coverage makes the most fiscal sense. The value of the car is less than the deductible amount, so collision and comprehensive coverage are not selected. However, the value of vehicle 2 is still significant. It would be riskier to select the minimum coverage package for vehicle 2 because that provides no coverage for vehicle repair or replacement costs. For the newer vehicle, a possible risk-averse option would be a hybrid policy containing the minimum Floridamandated coverages along with some collision and/or comprehensive coverage to cover vehicle residual value. A reasonable compromise for that cost would be between the minimum and standard package premium for a six-month time frame.
It makes little fiscal sense for the college student with an old car and minimum assets to purchase extra coverage. While the minimum package coverages are sufficient for a newer vehicle, buying collision and/or comprehensive coverage would reduce the asset loss risk.

\section{References}

Florida Department of Highway Safety and Motor Vehicles. (2017). Vehicle Insurance Questions and Answers.

Retrieved April 16, 2017, from http://www.flhsmv.gov/ddl/ frfaggen.html

Insurance Research Council. (2017). One in Eight Drivers Uninsured: Countrywide Rate Increases as Several States Experience Significant Decrease. Retrieved March 23, 2017, from https://www.insurance-research.org/sites/default/files/ downloads/UMNR1005.pdf

Kelley Blue Book. (2017). Your Blue Book ${ }^{\circledast}$ Value. Retrieved March 23, 2017, from https://www.kbb.com/car-insurance/ 
Table 1. Case study options comparison using large insurance company in year 2017* (Kelley Blue Book, 2017).

\begin{tabular}{|c|c|c|c|}
\hline Coverage & Minimum Package Coverages & Standard Package Coverages & Upgrade Package Coverages \\
\hline Bodily Injury Liability & $\$ 10,000 / \$ 20,000$ & $\$ 50,000 / \$ 100,000$ & $\$ 100,000 / \$ 300,000$ \\
\hline Property Damage Liability & Property: $\$ 10,000$ & Property: $\$ 50,000$ & Property: $\$ 100,000$ \\
\hline Personal Injury Protection & $\begin{array}{l}\$ 10,000 \text { emergency condition } \\
\$ 2,500 \text { no emergency condition }\end{array}$ & $\begin{array}{l}\$ 10,000 \text { emergency condition } \\
\$ 2,500 \text { no emergency condition }\end{array}$ & $\begin{array}{l}\$ 10,000 \text { emergency condition } \\
\$ 2,500 \text { no emergency condition }\end{array}$ \\
\hline $\begin{array}{l}\text { Uninsured Motorist } \\
\text { Underinsured Motorist }\end{array}$ & No coverage & No coverage & No coverage \\
\hline Collision & No coverage & $\$ 500$ deductible & $\$ 500$ deductible \\
\hline Comprehensive & No coverage & $\$ 500$ deductible & $\$ 500$ deductible \\
\hline Medical Payments & Not elected & Not elected & Not elected \\
\hline Vehicle & $\begin{array}{l}\text { Minimum Package Cost per } 6 \\
\text { Months }\end{array}$ & $\begin{array}{l}\text { Standard Package Cost per } 6 \\
\text { Months }\end{array}$ & $\begin{array}{l}\text { Upgrade Package Cost per } 6 \\
\text { Months }\end{array}$ \\
\hline $\begin{array}{l}1996 \text { SUV }^{* *} \\
\text { Value }=\$ 324.00\end{array}$ & $\$ 1,092.78$ & $\$ 1,706.97$ & $\$ 2,063.10$ \\
\hline $\begin{array}{l}2015 \text { CUV } \\
\text { Value }=\$ 18,339.00\end{array}$ & $\$ 1,468.37$ & $\$ 2,102.38$ & $\$ 2,436.87$ \\
\hline \multicolumn{4}{|c|}{$\begin{array}{l}\text { * The specific name of the large insurance company is withheld due to non-endorsement concerns but is available upon request from the } \\
\text { student author for purposes of reference verification or for additional referencing purposes. } \\
\text { ** The make and model of vehicles } 1 \text { and } 2 \text { have been withheld due to non-endorsement concerns but are available upon request from the } \\
\text { student author for purposes of reference verification or for additional referencing purposes. }\end{array}$} \\
\hline
\end{tabular}

